\author{
Maryna TARNAVSKA, \\ orcid.org/0000-0002-5476-911X \\ Candidate of Philological Sciences, \\ Associate Professor at the Department of Translation, Applied and General Linguistics \\ Volodymyr Vynnychenko Central Ukrainian State Pedagogical University \\ (Kropyvnytsky,Ukraine) tarnavsky78@gmail.com
}

\title{
CONSCIOUS SUBTEXTS OF SALINGER'S STORIES THROUGH THE PRISM OF THEIR INTERTEXTUALITY AND METATEXTUALITY
}

The article provides an insight into the problem of implicit meanings of a literary text and their rendering in the course of translation. The texts of J. D. Salinger's stories were chosen to study the mechanism of hidden meanings functioning, as the subtext of Salinger's artistic writing was created by him consciously. The latter fact provides a certain level of objectivity in the analysis of his works. The research focuses on the mechanisms of subtext creation, highlights the types of hidden meanings and summarizes the techniques and means that build implicit meanings of a work of art. The main principle of subtext generation is vector unidirectionality, that is, the focus of all artistic means of the text on the creation of a particular idea or link. The notion of suggestion, which is a way of "hidden meaning imposure», is important for understanding Salinger's subtextual writing, as it is a unifying force, a central vector that builds the implicit planes of an artistic text. Another important problem in the study of subtextuality is the problem of its adequate rendering in the process of translation. Whereas the translator's focus might be on the author's explicit meanings and style, subtexts can often be lost beneath the the translation. In order to achieve maximum possible adequacy of the subtext, the translator ought to, in the first place, be aware of the presence of these hidden layers of the work. That is why the highest degree of translation adequacy might be achieved while translating artistic texts with a consciously created implicit meaning. Another important task is to identify the types of hidden meanings present in the work, as well as the so-called «singlevector chains» of artistic techniques aimed at subtext generation. Only under the condition of accurate identification of such a system of subtextual means can we talk about the adequacy of literary text interpretation in the process of its translation. The article also outlines the prospects for further research on the problem of subtext in its connection with intertextuality and metatextuality, which are integral elements of any highly artistic subtext writing.

Key words: subtext, implicit meaning, suggestion, semantic vector, intertextuality, metatextuality, adequate translation.

Марина ТАРНАВСЬКА, orcid.org/0000-0002-5476-911X кандидат філологічних наук, доиент кафедри перекладу, прикладної та загальної лінгвістики Центральноукраїнського державного педагогічного університету імені Володимира Винниченка (Кропивницький, Украӥна) tarnavsky78@gmail.com

\section{СВІДОМО ТВОРЕНІ ПІДТЕКСТИ ОПОВІДАНЬ СЕЛІНДЖЕРА КРІЗЬ ПРИЗМУ ІНТЕРТЕКСТУАЛЬНОСТI ТА МЕТАТЕКСТУ}

Статтю присвячено дослідженню проблеми підтекстових смислів художнього тексту та їх передачі під час перекладу. Для вивчення механізму дії прихованих смислів були вибрані тексти оповідань Дж. Д. Селінджера, оскільки підтекстовість художнього письма Селінджера створювалась ним свідомо, щяо забезпечує певний рівень об 'єктивності під час аналізу творів. Дослідження фокусує увагу на механізмах творення підтексту, увиразнює види прихованих смислів та узагальнює прийоми та засоби, щуо вибудовують імпліщитні смисли художнього твору. Основним принципом побудови підтексту є одновекторність, тобто спрямованість усіх художніх засобів тексту на створення певної ідеї або посилання. Поняття сугестії, як прийому «навіювання» прихованих смислів, є важливим для розуміння підтекстового письма Селінджера, адже вона є об'єднуючою силою, иентральним вектором, щчо вимальовує імпліцитні плани художнього тексту. Іншою важливою проблемою дослідження підтекстовості є проблема адекватної ї̈ передачі під час перекладу. Оскільки ичентром уваги для перекладача є поверхневий смисл та стиль автора, приховані смисли часто можуть губитися або втрачати свою виразність на тлі експліцитного перекладу. Щоб досягти максимально можливої адекватності передачі підтексту, перекладачеві необхідно передусім усвідомлювати наявність таких прихованих шарів твору. Найефективніше ие завдання можна розв'язати, перекладаючи художні тексті зі свідомо твореним імпліцитним смислом. Іншим важливим завданням є ідентифікаиія видів прихованих смислів, наявних у творі, а також так званих «одновекторних ланцюгів» художніх прийомів, спрямованих на генерування підтексту. Тільки за умови 
точної ідентифікаиії такої системи підтекстових засобів можна говорити про адекватність інтерпретаџіі художнього тексту в проиесі його перекладу. Стаття також окреслює перспективи дослідження проблеми підтексту в ї̈ зв 'язку з інтертекстуальністю та метатекстуальністю, щзо є невід 'ємними супутниками високохудожнього підтекстового письма.

Ключові слова: підтекст, імпліџитний смисл, сугестія, смисловий вектор, інтертекстуальність, метатекстуальність, адекватний переклад.

Problem under consideration. Subtext is an inseparable and essential part of any literary work of the highest quality, that is why to comprehend the depth of the text artistic merit is to a graet extend to identify all the hidden planes it might contain. These imoplicit layers supply the text with the magnetic power to stir the feelings and provoke a range of thoughts making it alive capable of merging with the readers own perceptopns and even altering them. That is what we call artistc power and that is what every genius literary work possesses. The series of articles on this subject is united by the works of J. D. Salinger, who is known to have been an unsurpassed master of consciously created subtext. Thus, the objectives of the article are to "unveil" the hidden meanings of Salinger's stories, to show the process of subtext formation, to highlight the intertextual motives of Salinger's works, and to provide guidelines for adequate translation of those elements of the literary text. The object of our research is the subtextual meanings of a work of art, and the subject is a set of artistic means that create and reinforce hidden plans of a work of art, as well as their interpretation and translation methods. The study is relevant as in literary texts with deliberately created hidden meanings, the identification and interpretation of those meanings helps to approach the writer's intention, to emphasize and express the explicit meaning. In the process of translation, understanding as well as preserving the implicit planes of the work of art, and hence the adequacy of its translation, depend on accurate rendering of the mechanisms of their creation.

The latest research analysis. The problem of interpretation and translation of hidden meanings in a literary text was studied by renowned scholars who shaped the traditional approach to subtext interpretation (Haleeva N. L., Halynska I. L., Hrintser P. A., Zorivchak R.P., Kukharenko V.A., Miller J.), whereas there is the whole bunch of recent insights into the matter of subtext which closely connect the notions of subtext, intertext and metatext building up a new foundation for a modern comprenensive theory of subtext generation and interpretation (Fateeva N A., Kondratenko N. V., Pryhodko V. B., Hrek L. V.). In spite of the fact that subtext is a subtle thing, which is not given a profound definition and nature description, it is a key to the analysis of a literary text, thus remains of the highest importance and relevance to the scholars of the field.

The article is aimed at providing the overview of consciously created subtext generation as well as its functioning in a literary text, revealing the basic ways it is cabable of nfluencing the readers' comprehension. The research highlights the system of means to create the implicit meanings and shows its relation to intertext and metatext. In addition, there is an attempt to outline the most essential aspects of adequate translation of the literary pieces containing the subtext.

The main body of the article. The cycle "Nine Stories" was written by Salinger in accordance with the canons of ancient Indian poetics "dhvani" (Гринцер, 1987), according to which the work of art creates additional, unspoken images beyond the picture that is created by the words used" (Гринцер, 1987: 81). There are nine such moods in the poetic theory of "race" (Гринцер, 1987: 135-136), and Salinger gave each of his stories one of those sentiments (Галинская, 1975: 30). For instance, "A Perfect Day for Bananafish" reveals the feeling of love, "Just before the War with the Eskimos" embodies the pathetic mood of pity and compassion, the poetic mood of the story "For Esmé - with Love and Squalor" is "fear", and because, according to Indian poetics, these moods must be "manifested", that is implicitly expressed, the main and favorite way of its suggestion in Salinger is the subtext. The purpose of writing a series of "Nine Stories" for Salinger was to embody, "suggest" all nine basic feelings of Indian poetics, and this task might have required the writer of certain artistic sacrifices (interestingly, Tulsi Das, author "Ramayana" is considered to be the only Indian classic writer who managed to use all the poetic sentiments of Sanskrit poetics in his work (Галинская, 1975: 51)).

We have repeatedly noted that the style of Salinger's subtextual writing is characterized by certain features (Tarnavska, 2020). Thus, his works are characterized by multifaceted "polyphonic" subtexts, artistic means that «manifest» the subtext (for example, repetitions, "associative nets", artistic details, metaphors), as well as intertextuality. The latter occupies a special place in the paradigm of Salinger's writing, because it serves a kind of a connecting chain between the explicit and hidden meanings of the writer's works, gives the keys to their interpretation. 
The primary and most obvious tool to create the subtext is the composition of Salinger's stories, which resembles a dramatic work, that is, has a limited "space-time" plane, consists of clear structural parts, and is one of the favorite ways to create a mood, pushing the reader to deeper thinking into the text. Let us say, in "Just before the War with the Eskimos" the first part, the dialogue of school friends Ginny and Selina, immediately creates tension. The images of the girls, as well as their lines, are built on the principle of contrast (also Salinger's favorite trick!) Selina, the rich daughter, does not want to pay her share for a taxi, and Ginny does not give up, full of anger and determination to return their money. At first glance, there is no sympathy here, but this heated quarrel over a petty sum creates the basis, prepares the reader for the real feeling that they should experience. And then there are tiny but, important as ever details of the "associative net»: Ginny mentions the small amount of money she gets every week, and Selina tries to make her friend feel sorry for her supposedly sick mother. Reasons for compassion are trivial, but they are in contrast to the real feeling. The second part, actually the main one in terms of meaning and emotions, shows the real tragedy of the ruined "young" life of Celine's brother, Franklin, and in fact makes the reader sympathize with Ginny. And again, the contrast, this time in a strong position the end of the story: Ginny cannot throw away her as she feels sorrow similar to the one felt Franklin's dead chicken a dead chicken. And here, traditionally for Salinger, the ending acquires a metaphorical meaning: "dead chicken" symbolizes something young, defenseless and irreversible, something reminiscent of joy and life, but at the same time of death and hopelessness. With such a metaphor, it is simply impossible not to be embraced with pity and compassion, and this mood is no longer just a girl's sympathy for a young man, a pity for the reader, for a dead bird or for a girl who takes it so close to heart. This is a universal, all-encompassing feeling for the world, which is what Salinger eventually sought to achieve. As we can see, the writer creates the emotional subtext "dhvani" with the help of traditional means, and this is quite logical, because his subtext is consciously created. However, Salinger's texts have another unifying feature - they are «soaked» with intertextual connections or motifs. These connections play an extremely important role: first, they often combine works of different styles and forms into a single "story", and also are able to create additional and reinforce existing subtextual meanings.

Intertextuality with Salinger is primarily realized by means of "themes" or "motives", which can be easily traced in his works. Among the most common ones is the "school" motive: in "Just before the
War with the Eskimos" two friends study in the same school. Also the «school» theme is most noticeable in the novel "The Catcher in the Rye", where the main character is a teenage schoolboy. If we look closely at the laconic image of Ginny, we can see a lot in common with Holden: the same sharpened sense of injustice and ability to feel the pain and sorrow of others. The latter fact is especially interesting for our analysis, as Holden in "The Catcher" often finds himself in situations in which the reader sympathizes with him, and sometimes Holden even sympathizes with himself. Through the prysm of "The Catcher in the Rye", the pathetic mood of "comassion" of the short story takes on even brighter colouring.

Another important intertextual motif by Salinger is children, "as the only salvation from the horrors of human existence" (Галинская, 1975: 58). Like Esme in "For Esmé - with Love and Squalor", the other characters of the works play a key role in understanding and interpreting their meanings. Thus, Teddy from the story with the same name is endowed with the mind and foresight of a sage, not only does he accept the imperfections and misery of the world, but is also able to understand and forgive, feel almost divine love for people. Four-year-old Lionel from the story "Down at the Dinghy" has the courage to stand up to the world of adults, showing faith in his father, a determination to defend him to the end. And undoubtedly Sybil from "A Perfect Day for Bananafish", who, like the main character, looks at the world "differently": with love, without fear and conventions. Interestingly, in the story "For Esmé - with Love and Squalor" there is an almost identical episode when little Charles, like Sybil, who claims that the blue bathing suit is actually yellow, is not afraid to call things the way they appear to him: "He certainly has green eyes. Haven't you, Charles?" ... "They're orange", he said in a strained voice, addressing the ceiling".

The subject of war was very close to Salinger, as he himself took part in World War II, worked with prisoners of war and liberated prisoners of concentration camps. It is obvious that the life of an individual soldier, his psychological state and feelings, were perfectly clear to the writer. The motif of a man, a soldier, whose fate and soul are mutilated by war, is the key one in a range of writer's works, especially in "A Perfect Day for Bananafish". An interesting paradox: the life of Seymour Glass is tragically cut short, as he does not survive through "after the war" life, while Sergeant X from "For Esmé - with Love and Squalor" eventually gets hope for the future, although "enlightenment" is experienced by both, and it comes to the characters through children, their purity and 
faith in people. On the other hand, the poetic mood of "A Perfect Day for Bananafish" is love (Галинская, 1975: 36-38), and the story "For Esmé - with Love and Squalor" is fear (Галинская, 1975: 59-61). How can such a discrepancy be interpreted? Again, the answer is the subtext. In "Banana Fish" Salinger uses the technique of metaphor by contrast (in ancient Indian poetry - "akshena") (Галинская, 1975: 44): Seymour cuts his life, short, because it is the source of suffering and pain, his act is a step to nirvana, to the eternal peace and love. The same "hidden contradiction of utterance" is observed in the story "For Esmé - with Love and Squalor": he is alive, but the existence of a man whose mind is crippled by war is a complete horror. That is the explicit meaning of these stories, and the intertextual connections reinforce the suggested mood in them.

One more significant feature of the subtext writing is "iceberg principle" indeed. It lies in the assumption that the most valuable in terms of meaning information is hidden "behind the lines". It is frequently realized through the dialogue, and Salinger is not an exception. However, his subtextual "icebergs", despite having their distinct feature, are never quite the same. In most cases these are just short sentences, bearing traces of hidden emotions, omens of something to happen soon, like in "Down at the Dinghy" or in "A Perfect Day for Bananafish". But they can be quite unusual, like with "For Esmé - with Love and Squalor". In its first part, which, traditionally for Salinger, we have a leisurely story of the protagonist, who describes the events of his life at the beginning of the war. And only later the author introduces a dialogue between the character and Esme, which, is filled with hidden meanings an experienced reader is supposed to find. The second part, the character's confession at the end of the war, also does not resemble the traditional Salinger dialogue, but is rather a reasoning. However, such illogicality occurs only at first glance. In fact, the main form of presentation of events is the same dialogue, only this time it is a conversation of the character with himself, with his inner child. Here we might be able to interpret this unusual form of presentation by referring to the intertextual connections of the text and to the metatext. As we have repeatedly noted, these connections play an extremely important role, as they often combine works of different styles and forms into a single "story", as well as being able to create additional and reinforce existing subtextual meanings (Tarnavska, 2017). Yet again, the iceberg primciple would never work by itself. Salinger's dialogues are filled with motifs, associative nets, repetitions and allusions, all together creating a completely different, much deeper and versatile impression of the text.
Remarkably, Salinger's "dhvani", that is an implicitly created poetic mood, can serve the purpose of metatextual link creation (Allen, 2000). Thus, the poetic mood of the story "For Esmé - with Love and Squalor" is "fear", but, traditionally for Salinger, this mood is suggested imperceptibly, indirectly, so the means of its expression should be sought in the subtext. In the first part of the story, fear is carefully hidden in the description of the lives of soldiers preparing to land in Europe, as well as expressed in the depiction of the weather, which is rainy and gloomy ("the flashes of lightning", "raining even harder", "slanting, dreary rain", "rainy, rainy day", "certainly a terrible day out"). However, fear in this part is nonmaterial, it is rather some kind of anxiety, anticipation of something ominous. In the second part, the fear materializes: the character is deeply depressed, the fear of living further deprives him of his strength. There is an episode where Sergeant X opens Goebbels' book left by the Nazi, reads an inscription made by her - "Dear God, life is hell", and then adds with his hand "Fathers and teachers, I ponder "What is hell" I maintain that it is the suffering of being unable to love" seized by the fear of realizing the meaning of these words for himself. The culmination of the suggestion of fear - the fear of the Nazi threat, the ruthlessness and absurdity of existence is concentrated in this episode, giving expression to the suggested mood.

Salinger placed particular emphasis on the titles of his works, which, like the ending, were meant to send the readers' thoughts deep into the text, forcing them to search for hidden planes. One of the stylistic means frequently employed with the titles is pun or better say play on words based on polysemy. Taking into account the essential polysemantic nature of the English language, the title interpretation in the process of translation might definitely be a complexity. The title "For Esmé - with Love and Squalor" is no exception. The fact that the character dedicates his writings to the girl emphasizes her role in his life, but for the translator a special challenge is presented in the word "squalor", which is later mentioned in the text, though it does not clarify, but only comlicates the story. Esme, learning that Sergeant X is a writer (by the way, again an intertextual motive, because most of Salinger's main characters are artistically gifted individuals), asks to write something for her that contains a lot of "squalor". The dictionary gives the following definitions of this word: 1) "dirt", "neglect", "misery"; 2) "moral degradation", "moral weakness". It is likely that Salinger deliberately put this word in the girl's mouth, because despite the manner of pouring "smart" remarks, she does not fully understand 
(or may not understand) this ambiguous and rarely used literary word. Such a paradox, coupled with repetitions throughout the text and a strong position in the title, hints at the hidden meaning that the writer proposes to reveal. Obviously, Salinger hints at the misery of the world, which is crippled just like Sergeant $\mathrm{X}$. On the other hand, this word, uttered by a little girl, is a symbol of salvation and ought not to sound rude, "dirty", otherwise the author could pick up a less ambiguous word.

Undoudtedly, creation of subtextual meanings takes place by means of the whole system of techniques, among which artistic detail stands out as far more important. An artistic detail can work to create several implicit planes of an artistic text. It can serve a multifunctional purpose. In the story "Pretty Mouth and Green My Eyes" it helps to build psychological subtext, aimed at revealing the inner state of the characters, their true feelings and experiences, as well as emotional, created by the canons of ancient Indian poetics and aimed at suggesting a certain emotional state of the reader, in this case, a sense of disgust.

The details that work to create a psychological connotation are mainly the features of the characters, gestures, facial expressions. The expressiveness of artistic details which produce an emotional subtext is achieved by creating contextual repetitions or "associative nets" - details appear throughout the story in different contexts and with varying meanings, which determines their multi-associative functions and the creation of hidden emotional influences. An artistic detail can be so expressive in terms of making associations and moods, thus it can be considered a symbol in terms of function, such as the detail of the "ashes" or the color of the eyes in Salinger's story.

The role of artistic detail in creating the subtext determines the importance of its adequate rendering in the translation process. Therefore, understanding the mechanisms of building up implicit meanings, which helps to correctly identify important details of the literary text, makes it possible to achieve a greater approximation of the translation to the original text. Artistic details can carry several meanings, including symbolic ones, if they work to build different subtextual planes. Hence, it is essential in the translation to take into account this possible multi-layered subtexts, so that the detail in the translation performs the same functions as in the original, and the reader perceives it as adequately as possible to the author's intention. The next important element of creating a subtext are the key details-symbols. These are usually polysemantic words, several meanings of which might highlight one and the same idea, which is often a hidden meaning.
Of course, working with the translation of hidden meanings is extremely laborious and it is often simply impossible to find and take into account all the key points of creating a subtext that can affect perception, but striving for their utmost reproduction is a task, even a challenge for the translator. Here again we must mention the importance of "background" information about the text, namely the knowledge that the subtext is consciously created, knowledge of the basic ways of creating subtexts by the writer, knowledge of his philosophy, intertextual motives, historical context and more (Фатеева, 2007: 121). Moreover, this information is important not only for the translator, but also for the reader, and therefore comments to the text, explanations of the basis of the work, options for interpretation of certain parts of the text seem absolutely necessary stages to follow. For instance, the name of one of the main characters of Selena's story in "Just before the War with the Eskimos" is the name of the ancient Greek goddess Luna as well as in ancient Indian poetics Luna is associated with compassion and mercy (Галинская, 1975: 31). However, Salinger's Selena is a negative character, rather the opposite of such an image, and therefore the writer uses a double artistic technique: the imagery of the name and the favorite principle of contrast. It is clear that without post-text commentary it is almost impossible to understand this subtextual motive.

Conclusions and further research prospects. To conclude, we will make some important generalizations about the interpretation and translation of the subtext Salinger's stories. First of all, works of art with consciously created implicit meanings require scrutinizing attention of the translator, as it is often the case that hidden meanings not only emphasize the explicit ones, but also create the emotional plane of the work. While modelling the subtexts of the kind, the author usually uses distinctive artistic means and techniques (namely, Salinger's dialogues are built on the "iceberg principle", repetitions, semantic puzzles, tokens, symbols, etc.). If the translator is well aware of these key points in the creation of the subtext, subtextual meaning rendering becomes more adequate. It is also essential for the translator to be equipped with the «background» information, against which the subtexts might have been created. For Salinger's writing, in particular, it is the implementation of the philosophy of Zen Buddhism and the canons of ancient Indian poetics. And, last but not least, when it comes to the translation of Salinger's works, it inevitably involves interpretation of a variety of intertextual connections that his texts are saturated with, which can influence both explicit and implicit meanings of the work and which the translator ought to take into account. Tak- 
ing into account a large amount and diversity of background information that can affect the adequacy of text comprehension, it seems absolutely necessary for the translator to deploy footnotes and post-text commentaries, including explanations of some features of translation to bring the reader closer to the meanings of Salinger's texts. Since subtextuality and intertextuality are the principles on which most modern literary texts are based, the prospect of our further research may be the interpretation and study of the features of adequate translation of other works with consciously created subtext.

\section{BIBLIOGRAPHY}

1. Галинская И. Л. Философские и эстетические основы поэтики Дж. Д. Сэлинджера. Москва : Наука, 1975.110 с.

2. Гринцер П. А. Основные категории классической индийской поэтики. Москва : Наука, 1987. 312 с.

3. Сэлинджер Дж. Избранное. Москва : Прогресс, 1982. 438 с.

4. Фатеева Н. А. Интертекст в мире текстов: Контрапункт интертекстуальности. Изд. 3-е, стереотипное. Москва : Ком Книга, 2007. 280 с.

5. Allen G. Intertextuality. NewYork : Routledge, 2000. 238 p.

6. Genette G. Palimpsests: literature in the second degree / Transl. Newman Ch., Doubinsky C. Lincoln. NE, London : University of Nebraska Press, 1997. 490 p.

7. Irwing W. Against Intertextuality. Philosophy and Literature. 2004. № 28.2. P. 227-242.

8. Tarnavska M. Literary Subtext Interpretation: the Power of Suggestion. Наукові записки. Серія: Філологічні науки. Кропивницький : Видавництво «КОД», 2020. Вип. 187. С. 623-628.

9. Tarnavska M. Subtext Generation: Mechanics and Perception. Наукові записки. Серія: Філологічні науки (мовознавство). Кіровоград, 2017. Вип. 154. С. 177-182.

10. Van Zoonen L. Intertextuality. The International Encyclopedia of Media Effects / P. Rössler, C. Hoffner C., L. van Zoonen. (eds).Wiley-Blackwell, 2017. P. 193-195.

\section{REFERENCES}

1. Galinskaya I. L. Filosofskie i esteticheskie osnovy poetiki Dzh. D. Selindzhera. [Philosophical and Aesthetic Basis of J.D.Salinger's Poetics]. Moskva: Nauka, 1975. 110 p. [in Russian].

2. Grincer P.A. Osnovnye kategorii klassicheskoj indijskoj poetiki. [Basic Categories of Classical Indian Poetics]. Moskva: Nauka, 1987. 312 p. [in Russian].

3. Selindzher Dzh. Izbrannoe. [Selected Works]. Moskva: Progress, 1982. P. 438.

4. Fateeva N. A. Intertekst v mire tekstov: Kontrapunkt intertekstualnosti. [Intertext in the World of Texts: Intertextuality Counterpoint]. M.: Kom Knyha, 2007. 280 p. [in Russian].

5. Allen G. Intertextuality. NewYork: Routledge, 2000. 238 p.

6. Genette G. Palimpsests: literature in the second degree / Transl. Newman Ch., Doubinsky C. Lincoln NE, London: University of Nebraska Press, 1997. 490 p.

7. Irwing W. Against Intertextuality. Philosophy and Literature. 2004. № 28.2. P. 227-242.

8. Tarnavska M. Literary Subtext Interpretation: the Power of Suggestion. Research Bulletin. Series: Philological Sciences. Kropyvnytskyi: «KOD» Publishers, 2020. Issue 187. P. 623-628.

9. Tarnavska M. Subtext Generation: Mechanics and Perception. Naukovi Zapysky. Kirovohrad, 2017. Nr. 154. P. $177-182$.

10. Van Zoonen L. Intertextuality. The International Encyclopedia of Media Effects / Rössler P., Hoffner C. and L. van Zoonen. (eds).Wiley-Blackwell, 2017. P. 193-195. 